\title{
Description of the Truck Driver's' Knowledge, Attitudes and Practices in Preventing Sexually Transmitted Infection at Transportation Service Provider in Bandung 2013
}

\section{Lidya Latifah Novianti}

Faculty of Public Health, Universitas Indonesia, Depok, Indonesia

\section{Abstract}

Sexually transmitted infections (STIS) and its complications are one of the health problems increasingly alarming. The truck drivers were one of the groups who are risky of carrying or being infected by STIs. They also identified as a group that improperly performed STIs prevention activities. Therefore, it is essential to determine their knowledge, attitudes, and practices related to STIs prevention.

This descriptive study aimed to describe the truck drivers' knowledge, attitudes, and

Corresponding Author: Lidya Latifah Novianti

lidyalatifahnovianti@gmail.com

Received: 26 December 2018 Accepted: 23 February 2019

Published: 7 March 2019

Publishing services provided by Knowledge

(c) Lidya Latifah Novianti. This article is distributed under the terms of the Creative Commons

Attribution License, which

permits unrestricted use and

redistribution provided that the

original author and source are credited.

Selection and Peer-review under the responsibility of the 2 nd International Meeting of Public Health 2016 Conference Committee. practices in preventing STIs transmission. Fifty-one respondents were recruited using total sampling technique. Data were collected using questionnaires, and collected data were analyzed using descriptive statistic, frequency dan percentage. The result showed there were 23 (45.10\%) respondents who had sufficient knowledge, 29 (56.86\%) respondents reported hostile attitudes and 26 (50.98\%) respondents who performed bad practices. Regarding knowledge, there were two items with the lowest score including wearing condoms and myths. In STIs practices, searching for information and wearing condoms there were two aspects with lowest scores. Thus it is recommended for nurses in the community level to improve their efforts in enhancing truck drivers' knowledge and attitude, particularly in using a condom, how HIV transmitted and correcting the myth-related STIs.

Keywords: Sexually transmitted infections; truck driver; prevention

\section{Introduction}

Along with the times, many changes happened. One of which is the change in social behavior. Social change is positive and also negative. One revision of negative response is violent free sex behavior which increased the risk of transmission of sexually transmitted infections (STIs).

Benson (2008), STI is an infection that mainly acquired through sexual contact. Mode of transmission of STIs is through unprotected sexual contact which is through genital but also includes oral-genital contact (oral-genital), kisses and the use of sexual "toys" 
Control STIS is a top priority for the World Health Organization (WHO). According to WHO in 2005, there were 448 million new cases of STIs (syphilis, gonorrhea, trichomoniasis, and chlamydia) occur every year throughout the world in adults around the age of 15-49 years. In developing countries, STIs and its complications included to fifth in the category of diseases that affect adults who require treatment (WHO 2011).

Integrated biological and behavioral surveillance (IBBS) in Indonesia to the truck drivers, motorcycle taxi drivers, sailor/crew and port workers in 2011 showed that HIV prevalence and STIs in truck drivers were very high. The incidence of HIV and STIs on truck drivers ranked first. This supported background that mostly truck drivers who frequently travel outside the city/province and away from their families or couples. The may encourage them to undertake risky sexual behavior (Anonymous 2011).

Besides the relatively high numbers, STIs identified caused many adverse effects both regarding physical, psychosocial, and financial. When a person exposed to STI, physical changes that can disrupt physiologically will occur (Cahyono 2008).

Thus vigilance and prevention of transmission by a couple who are a high-risk group of contracting are not executed in practice. Finally, contagion is inevitable and increasingly difficult to cure. Thus the prevention of STIs is essential.

Factors behind a truck driver in risky sexual behavior one of them are the job of migrating or moving (Dadun 2007). The position is switching or moving resulted in the truck driver, and the conductor seldom came home, the stress level ride height and encountered places that peddle sexually, including recognition by one source. These places are in Indramayu, Sumedang, Karawang and Purwakarta, motorists truck driver and conductor in a studied, stretch conveyance is public transportation that passes through some areas that peddling sex, so prone truck driver and the conductor to conduct free and risky sexual STIs infection.

From the preliminary study of the four truck drivers, several truck drivers say that STIs transmitted only between the genital organs, sexual intercourse with a partner is not wrong but still do not have sex with her partner. The use of condoms during intercourse with a partner is something that is not intrusive and considered unnecessary. 2 of 4 votes truck drivers say that the condom serves to avoid diseases caused by sexual intercourse and two others suspect only as a safety so that no unwanted conception.

From the above data, the truck driver was still lacking in preventing STIs. In a review of behavior, according to Bloom Notoatmodjo based theory, behavioral includes three (3) domains, i.e., knowledge, attitude and practice or action (Notoatmodjo 2005). In other words, STIs prevention will run correctly when the truck drivers have the experience, perspective, and ethical practices. 
The purpose of this study was to determine the knowledge overview of truck driver and conductor on the prevention of STIs, determine the description of the attitude of truck driver and conductor towards STIs prevention and identify the report of the driver and conductor's action in the STIs prevention.

\section{Methods}

The research design used was a quantitative descriptive (cross-sectional). Population and sample in this research were the driver and helper on a truck with a total of 41 drivers and ten conductors in the area of Bandung.

The instrument used was a questionnaire designed with the kind of enclosed survey, and content validity of the tests had conducted to expert lecturers in nursing maternity Faculty of the Nursing University of Padjadjaran. Data were analyzed using descriptive analysis; frequency, percentage, and T score.

\section{Results}

Characteristics of the study included education, marital status, number of wives or girlfriends, and get information. The following is a table of the frequency distribution for the characteristics of the respondent:

TABLE 1: Distribution Frequency of Characteristics of Respondents $(n=51)$.

Variables
Education
Not graduated from
Primary School
Elementary School
Junior High School
Senior High School
Marital Status
Married
Divorced
Single
Get Information
Ever
Never
Media Information
Television/radio
Magazine
Newspaper

\begin{tabular}{|c|}
\hline Frequency (f) \\
\hline 1 \\
\hline 7 \\
\hline 31 \\
\hline 12 \\
\hline 42 \\
\hline 5 \\
\hline 4 \\
\hline 27 \\
\hline 24 \\
\hline 2 \\
\hline 1
\end{tabular}

\begin{tabular}{|c|}
\hline Percentage (\%) \\
\hline 1.19 \\
\hline 13.73 \\
\hline 60.78 \\
\hline 23.53 \\
\hline 82.35 \\
\hline 9.8 \\
\hline 7.84 \\
\hline 52.94 \\
\hline 47.06 \\
\hline 81.48 \\
\hline 3.7
\end{tabular}


Based on Table 1, 31 respondents (60.78\%) attained a junior high school education level, 42 respondents (82.35\%) were married and married one with 39 (86.67\%) of respondents. A total of 27 (52.94\%) respondents claimed to have information about STDs, and most of the 22 (81.48\%) respondents obtained information from television/radio.

\subsection{An overview of the knowledge, attitudes, and actions of the driver and helper in the prevention of sexually transmitted infections}

TABLE 2: Distribution of Knowledge, Attitude, and Actions of Driver and Conductor in Sexually Transmitted Infection Prevention in Bandung District $(\mathrm{n}=51)$.

\begin{tabular}{|c|c|}
\hline Aspect & Knowledge Category \\
\hline \multirow[t]{3}{*}{ Knowledge } & Good \\
\hline & Enough \\
\hline & Less \\
\hline \multirow[t]{2}{*}{ Attitudes } & Support \\
\hline & Do Not Support \\
\hline \multirow[t]{2}{*}{ Action } & Good \\
\hline & Bad \\
\hline
\end{tabular}

\begin{tabular}{|c|}
\hline Frequency \\
\hline 12 \\
16 \\
23 \\
22 \\
\hline 29 \\
25 \\
\hline 26 \\
\hline
\end{tabular}

\begin{tabular}{|c|}
\hline Total (\%) \\
\hline 23.53 \\
\hline 31.37 \\
\hline 45.1 \\
\hline 43.14 \\
\hline 56.86 \\
\hline 49.02 \\
\hline 50.98 \\
\hline
\end{tabular}

Table 2 shows nearly half of respondents (23 respondents/45.10\%) were less knowledgeable, more than half of the (29 respondents/56.86\%) had an attitude does not support (unfavorable) and more than half of respondents $(50.98 \%$ ) had a bad precaution.

\subsection{Description of the data analysis, the driver and helper of knowledge about prevention of infectious}

TABLE 3: Distribution of the Driver and Helper of Knowledge about the Prevention of STIS $(n=51)$.

\begin{tabular}{|c|c|c|c|c|c|c|c|}
\hline \multirow[t]{2}{*}{ Aspect } & \multirow{2}{*}{$\begin{array}{l}\text { Descriptors } \\
\text { (Question) }\end{array}$} & \multicolumn{2}{|c|}{ Good } & \multicolumn{2}{|c|}{ Enough } & \multicolumn{2}{|c|}{ Less } \\
\hline & & $\mathrm{F}$ & $\%$ & $\mathrm{~F}$ & $\%$ & $\mathrm{~F}$ & $\%$ \\
\hline $\begin{array}{l}\text { Mode of } \\
\text { Transmission: }\end{array}$ & $\begin{array}{l}\text { Sexual } \\
\text { Intercourse }\end{array}$ & 8 & 15.69 & 29 & 56.86 & 14 & 27.45 \\
\hline \multirow[t]{5}{*}{ Prevention: } & & 11 & 21.57 & 19 & 37.25 & 21 & 41.18 \\
\hline & Sexual safe & 22 & 43.14 & 12 & 23.53 & 17 & 33.33 \\
\hline & Personal hygiene & 39 & 76.47 & 0 & 0 & 12 & 23.53 \\
\hline & Vaccination & 35 & 68.63 & 0 & 0 & 16 & 31.37 \\
\hline & Myth & 12 & 23.53 & 15 & 29.41 & 24 & 47.06 \\
\hline
\end{tabular}


Table 3 shows the distribution of the driver and helper of knowledge about modes of transmission and prevention of STIs. In the method of communication of the excellent presentation lowest category 8 (15.69\%) of respondents. Related knowledge in how to prevent STIs, $21(41.18 \%)$ respondents had less experience. The percentage of both categories is lower than $12(23.53 \%)$ are in the myths related to means of prevention of STIs.

TABLE 4: Distribution of the Driver and Helper of Knowledge about the Prevention of STIs based on the Item about the Lowest (Maximum Value $=1$ ).

\begin{tabular}{|l|l|c|}
\hline No item & Question & The Average Value \\
\hline 5 & Mode of transmission through oral sex & 0.549 \\
\hline 7 & $\begin{array}{l}\text { Mode of transmission of HIV to live } \\
\text { together and use of tools together }\end{array}$ & 0.490 \\
\hline 11 & The prevention of the use of condoms & 0.353 \\
\hline
\end{tabular}

Table 4 shows the results of each question on the knowledge that had the lowest average value, namely in the way of prevention by using condoms $(0.353)$.

\subsection{Description of the data analysis, the attitude of the driver and helper towards the prevention of STIs}

TABLE 5: Distribution of the Attitude of the Driver and Helper to the Efforts of STIs ( $n=51$ ).

\begin{tabular}{|l|c|c|c|c|}
\hline Descriptors & \multicolumn{2}{|c|}{ Support } & \multicolumn{2}{c|}{ Do not Support } \\
\hline & F & $\%$ & F & $\%$ \\
\hline Cognitive & 26 & 50.98 & 25 & 49.02 \\
\hline Affective & 26 & 50.98 & 25 & 49.02 \\
\hline Conative & 23 & 45.10 & 28 & 54.90 \\
\hline
\end{tabular}

Table 5 shows the distribution of the driver and helper's attitude towards the prevention of each descriptor, namely the category conative showed no support.

\subsection{Overview of the data analysis, the driver and helper action in the prevention of STIs}

TABLE 6: Distribution of the driver and helper action in the prevention of STIS ( $n=51)$.

Descriptors
Sexual safe
Personal hygiene
Myth

\begin{tabular}{|c|c|c|c|}
\hline \multicolumn{2}{|c|}{ Good } & \multicolumn{2}{c|}{ Bad } \\
\hline F & $\%$ & F & $\%$ \\
\hline 22 & 43.14 & 29 & 56.86 \\
\hline 39 & 76.47 & 12 & 23.53 \\
\hline 30 & 58.82 & 21 & 41.18 \\
\hline
\end{tabular}


Table 6 shows the distribution of the driver and helper action in the prevention of STIs each descriptor. Regarding percentage, the most excellent response contained in the personal hygiene with 39 (76.47\%) of respondents.

TABLE 7: Distribution of the Driver and Helper'sAction on the Prevention of STIs based on the Item about the Lowest (Maximum Value $=5$ ).

\begin{tabular}{|l|l|c|} 
No item & Question & Average Value \\
\hline 1 & Finding Information & 2.25 \\
\hline 3 & Use of Condoms & 2.33 \\
\hline 4 & Personal hygiene & 2.59 \\
\hline
\end{tabular}

Table 7 shows the result of the actions of every question that had the lowest average value, namely the search for information (2.25).

\section{Discussion}

Based on the results of the study, the results obtained with the picture less knowledge, attitudes and actions do not support wrong. In this study, the results followed the theory Notoatmodjo (2007) in which the behavior follows the stages that are knowledge, attitude, and action/practice, but the process is not always like that theory like someone had positive behavior through knowledge and belief was negative.

Regarding knowledge, by looking at the overall results of research on the prevention of STIs that include modes of transmission and prevention, it can be shown that the majority of respondents generally had less knowledge as many as 21 (41.18\%) respondents. The could happen in line with the factors that influence the behavior of education, educational level mostly as much as 31 respondents (60.78\%) last junior high education level.

Of the items in the analysis, in getting that knowledge is still lacking in the average value of them, namely, the use of condoms 0.35; prevention by taking antibiotics 0.39; prevention by choosing a sex 0.41 ; the modes of transmission of HIV to live at home and the use of cutlery together 0.41 ; method of communication through oral sex 0.54 ; it is the knowledge of the respondents were very limited so that could be a reference to the provision of information.

Knowledge through the means of HIV transmission is still lacking. Respondents even argued that by staying together and eat together tool wear could transmit HIVIAIDS. According to the Ministry of Health (2008), HIV can be transmitted through the transfer of bodily fluids of people infected with HIV. Displacement either from pregnant mother to fetus through the placenta, blood displacement of people infected with HIV through 
breast milk while nursing liquid, or through sexual contact with a person infected with HIV.

Knowledge-based on those myths, it is still relatively small; it indicates that these myths be the cornerstone of thinking of the driver and helper on a truck. In theory, the behavior of the above, other factors influences apart from the level of education, namely experience and environment. It can affect the formation of attitude, where the most useful attitude formation is from experience (Sarwono 2002). If this is allowed, then it could be the basis for the knowledge that one driver and helper on the truck, so the need for health promotion.

Respondents argued that taking antibiotics can prevent against STIs. Drinking with antibiotics such as penicillin, sepertetra, etc. before or after sex cannot kill all kinds of STDs even more frequently taking medications carelessly also complicate the healing because the body will be tolerant of the drug types ( $\mathrm{MOH} 2008$ ).

Choosing sex workers based on the outside cannot prevent STIs. According to the Ministry of Health (2008), those who suffer from herpes, hepatitis, and HIV chicken's comb, looked very healthy and clean except when the signs of the disease begin to appear obtained. Any child can be exposed and have an STI because STIS does not distinguish between age and did not look at anyone.

According to Notoatmodjo (2007), the knowledge that supports formed attitudes, when the experience of both the better the position, but it is not always absolute. This is proved by the perspective of the driver and helper on the prevention of sexually transmitted infection that most respondents, i.e., 29 (56.86\%) respondents have an attitude that does not support the (unfavorable). From the characteristics of the respondents, most of the respondents attained junior high school level of education, which is where, according to Notoatmodjo (2007) education falls under one of the factors influencing knowledge, whereas this knowledge affects a person's ability reasoning that supports the formation of attitudes.

According to Azwar (1995) in Maulana (2007), attitude formation influenced by several factors, namely personal experience, others that are considered essential, mass media, cultural, institutional or educational institutions, and religious institutions, and emotional factors within the individual. According to Marck (2002), the sexual culture of truck drivers has happened long ago. It makes a matter of course among truck drivers so that access to all prostitutes is also effortless.

The results of the attitude based on each of the components show the results do not support conative, while the cognitive and affective show results that support. This suggests that the trend in knowledge and attitude showed results that support and the 
tendency to act shows the results do not help. Compared to the effect of this attitude upside down with an overview of action studied.

According Sarwono (2002) for the three domains are inextricably linked, raised the theory that if we can determine a person's cognition and feelings toward a particular attitude object, we will know the tendency of behavior.

The action is to practice or carry out what is already known or encountered (considered good). An attitude does not automatically materialize in response (overt behavior). To realize the position becomes a real acts necessary supporting factor or a condition that allows (Efendi and Makhfudli, 2009). This can see from this study that the results of data analysis to show the attitude the attitude that does not support (unfavorable) but for the results of data analysis to action is good, with over half of respondents, i.e., 27 (52.94\%) of respondents.

United States Agency for International Development explain the factors that can affect infrastructure existing sexual behavior, the culture or customs stop/rest in the street, drugs/alcohol is readily available and used, working conditions, conditions of accommodation, sexual networks and stigma. This condition supported with working conditions that are prone to stress due to travel far and easy to obtain alcohol at the shop so vulnerable to risky sexual behavior. The spread of STIs is not only prostitutes to customers but can get to the family's home. Thus prevention of STIs is necessary to suppress the number of events.

In this research, there was still a lack of safe sex precautions in as many as 29 (56.89\%) respondents, whereas safe sex is an act of the most reliable in term of STIs prevention. This consists of sustained sexual abstinence (faithful partner) and the use of condoms during sexual intercourse ( $\mathrm{MOH}, 2008)$.

Personal hygiene respondents after sexual intercourse had an average value of 2.59. Arifin, Ginandjar, and Udoyono (2012) found the incidence proportion of STIs more in WPS that do not use antiseptic to clean the genitals of (70.5\%) compared to the WPS that often use sterile to cleanse the genital organs of (40.4\%),

The lower the measures preventive health behaviors, the higher the risk of acquiring STIs (Chandra2012). STIs prevention at its core by the MOH (2008) was abstinence, being faithful to each other in pairs, prevented by condoms, avoid drug use syringes, and education partner and friend.

To increase knowledge, attitudes and actions are necessary preventive measures, i.e., for example from health centers because according to six basic programs, one of which is the promotion of health and combating STIs, which operate in involving nurses, especially in the field of community that the main focus of the nursing community is to increase health and disease prevention. 


\section{Conclusions}

In conclusion, the knowledge of the driver and helper in the prevention of STIshave sufficient knowledge by 20 (39.22\%) respondents. Attitude of driver and helper towards the prevention of STIsdoes not support the (unfavorable) to 30 (58.82\%) respondents. Action of driver and helper in the prevention of STIs has shown good results with 29 (56.86\%) respondents. To improve knowledge and attitudes, it is advisable to provide information about the use of condoms, the impact of tattoos, how the spread of hiv, and to correct myths circulating in the community.

\section{References}

[1] Anonim. 2011. Surveilans terpadu biologis dan perilaku (STBP) pada kelompok beresiko tinggi di Indonesia tahun 2011. Available online at: http://www.orbit.or.id (diakses pada 25 Januari 2013).

[2] Arifin, Nur Fitriana, dkk. Penggunaan kondom dan vaginal higiene sebagai faktor risiko kejadian infeksi menular seksual pada wanita pekerja seks di lokasi Batu 24 Kabupaten Bintan. Available online at: http://ejournals1.undip.ac.id (diakses pada 14 Maret 2013)

[3] Benson, Ralph C, dan Martin L Pernoll. 2008. Buku Saku Obstetri dan Ginekologi edisi 9. Jakarta: EGC

[4] Cahyono, J.B Suharjo B. 2008. Gaya Hidup dan penyakit Modern cetakan ke-5. Yogyakarta: Kanisius

[5] Depkes, 2008. Anda HIV/AIDS dan STIS. Available online at: http://pppl.depkes.go.id (diakses 30 Maret 2013)

[6] Efendi, Ferry dan Makhfudi. 2009. Keperawatan Kesehatan komunitas Teori dan Praktik dalam Keperawatan. Jakarta: Salemba Medika

[7] Marck, Jeff. 2002. Long-distance truck drivers' Sexual Cultures and Attempts to Reduce HIV Risk Behaviour Amongst Them: a Review of the African and Asian Literature. Available online at: http:web.worldbank.org (Diakses pada 3 Mei 2013)

[8] Maulana, Heri D. J. 2009. Promosi Kesehatan. Jakarta: Penerbit Buku Kedokteran EGC.

[9] Notoatmodjo, Soekidjo.2007. Promosi Kesehatan dan Ilmu Perilaku. Jakarta: PT. Rineka Cipta.

[10] Sarwono, Sarlito Wirawan. 2002. Psikologi Sosial Individu dan Teori-teori Psikologi Sosial. Jakarta: Balai Pustaka. 
[11] WHO. 2011. Sexually Transmitted Infection. Available online at http://www.who.int/ (diakses pada 1 Maret 2013) 